\title{
Occurrence of Banded Chlorosis of Sugarcane in Puerto Rico
}

\author{
Jii-jang Liu, T. Rosario, and. F. Ménder. Rerig'
}

\section{INTRODUCIUN}

Puerto Rico, a tropical Island, lies in the 'Torrid Zone belween $\left.17^{\circ} \mathrm{z}_{\mathrm{i}}\right)^{\prime}$ and $18^{\circ} 31^{\prime}$ north latitude and $65^{\circ} 39^{\prime}$ and $67^{\circ} 39^{\prime}$ wost longitude within the Caribben area. The amnual average tomperature for the Istand is axound $78^{\circ} \mathrm{F}$. During the summer mouths, the average maximum temperature along the South Coast is frequently over 91"li. Thus, "ane in those areas has frequently suffered damage from drought and heat. In the early fart of Seprember 196t, chlorotic bandings were first observed at the Central-Aguire Sugar Co, on the loaves of P.R. 1059. Since P.R. 10i9) is a promising sugarcane varicty recently relensed to the sugar industry and cane growris in Puerto Rico, this unexpested trouble has raused concern. This variely has since been elosely observed. This paper reports findiugs of reconnaissance, particularly with reference to the incidenee of binded chlorosis on sugaranc.

\section{REVIEW OF TIE LITEKATIRL}

During the winter of $192 t-25$, faris (2) observed in Cuba peculian white bands on the Jeaves of yollow aledonia along the south roast of Habaua Province. By kecping molting ice above the growth point of the rane and permitting the boot of the eane 10 sland full of cold water for a period of three consecutive nights, he reproduced the white bands on the treated plauts. In Hawaii, (hlorolio bandings (3) have been observed on leaves of varieties H-109 and D-113j in the fields wilbin a fow weeks following periods of cold. Bub with cercals, Vindorpool in $1949(j)$ observed a similar chlorotic bunding on the recdlings when the soil surface was near fither the minimal or maximal temprature for growth. Of still grealey inceres is the occurrence of such chlorotic banding on sugarnane in the tropical areas of Australia during the hot periods that oreur at the stat of the xainy season. Banded chlorosis has never been reported on sugnrane: in Puerto Rico by the Stinding Committee on Sugureanc Dircases.

1 Assuciate Agronomist, Assistant Agromomist, and Agromonist, respectively, Agricultural Gxperiment Statinn, Cniversity of Puerto Rieo, Rio Piedras, P.ll.

"Itnlic numbers in paren (heses refor to Literature Cited, p. 81. 


\section{REST lils}

\section{DESCRIPTION OF THE SLIPTONS}

In the fall of 19 it several seriously affected fields were found at ('entral Iguire. The afferfed anos showed definte bands across the loutves, in which the ehlorophyll had prestmably failed to develop. . Mll of the centrit young leaves showed yellowish discoloralion at the caty slage (fig. 1), but later the affected areas separated and formed more definite bands. The

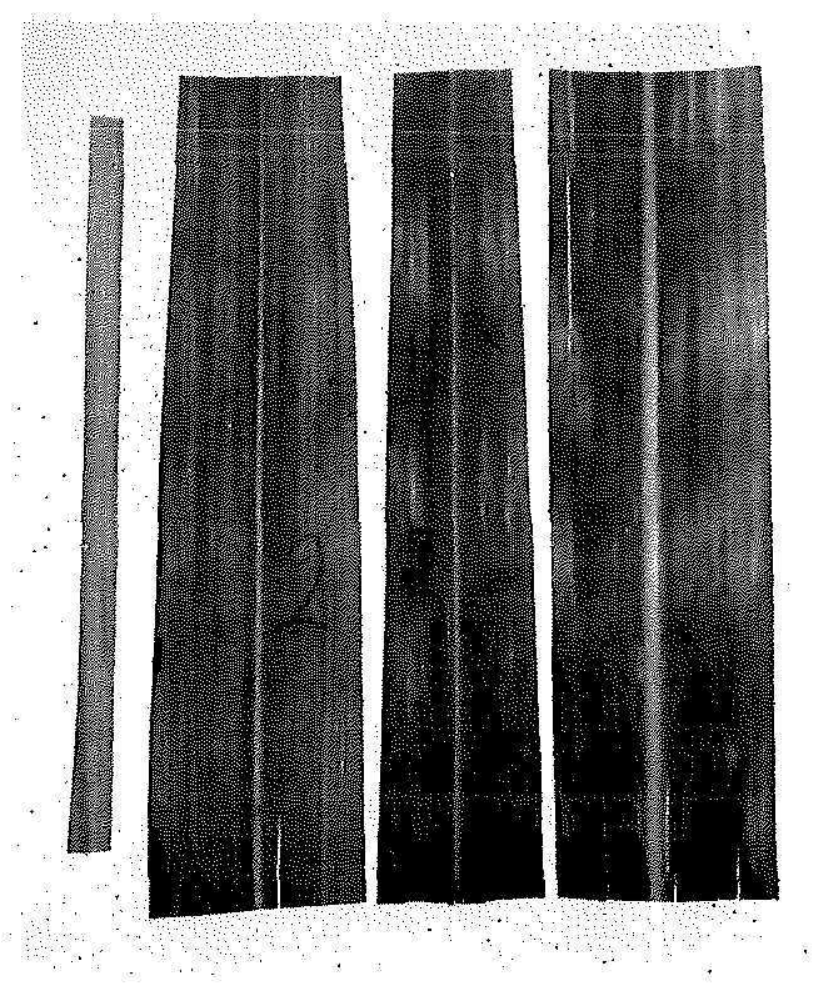

Fini, 1.--Symptoms of banded chlorosis observed at the eatrly stage on leaves of the sugareane variety P.1R. 1050.

bauds ranged from 5 (0 25) inches long and varied from a 1-inch narow stripe to a t-inch wide band which completely crossed the lcaf and gave the appearance that the injury might have occured in the young spindle before the leaves unrolled (fig. 2).

The rhlorotic bands, consisting of yellowish green horizontal areas of rhlorotic tissue occur at the bas of the older leaves and progressively higher towards the lijs of the successively younger leaves. These bands usually extend across the leaf on both sides of the midrib and have soldom bren observed on isolated stools in the finds. The border of the bands are irregular and often form distinct green stripu along the veins. The tissues 
between bundles atres sometimes xplit and aracked, thus leaving some

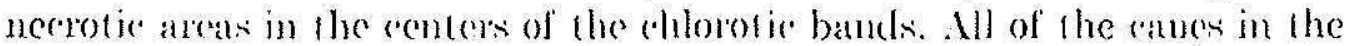

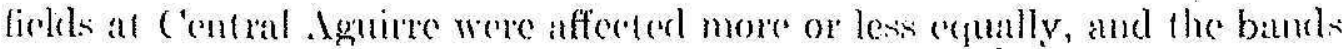

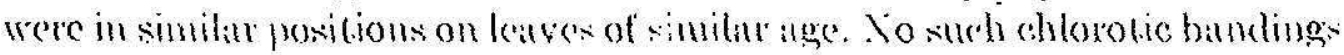

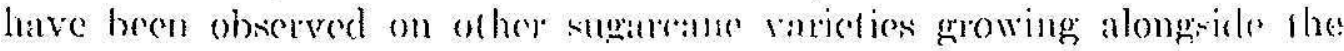
fields.

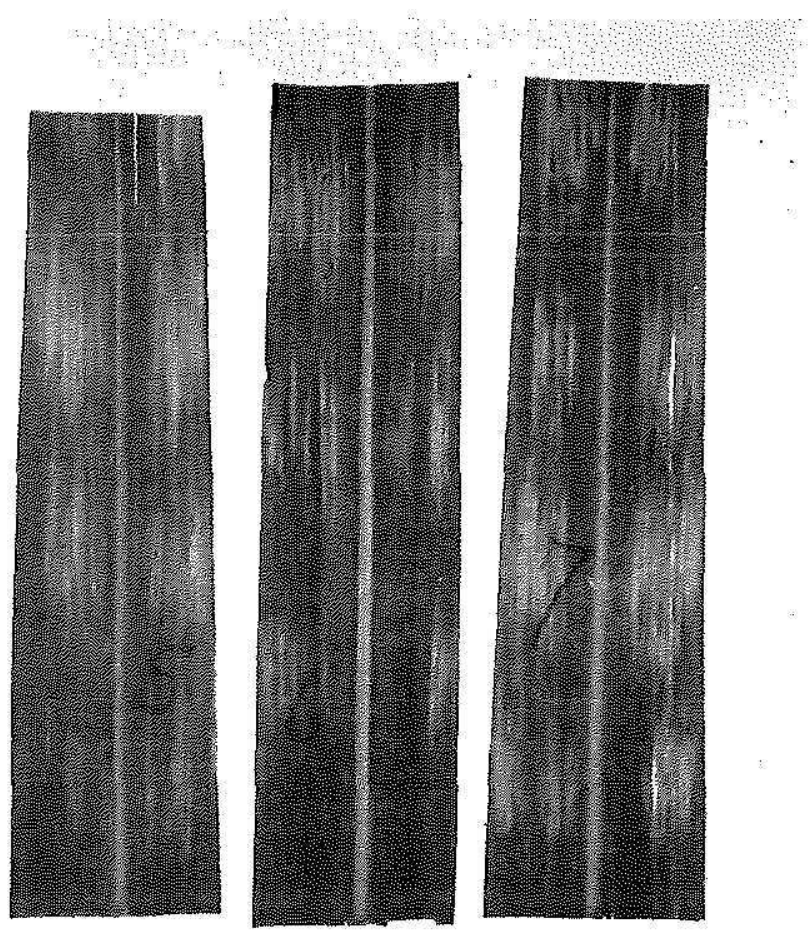

Fiti. 2. silmplesms of banded chlorusis observed at the late shage on leaves of the sllgarcane variety l', R. 10ist.

TDENTIFICATION ON CACRIJ . ICENT

Alfempts 10 identify the possible causid agent from either young or old lesion: by means of direct miresoscopic examination have been unsuecessful, alihough some fungi, such as Collofotrichum sp., Helminihosporium sp., apparently from sorendary inferetion, were seen in the necrotic neas.

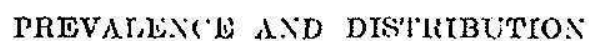

A survey wis conducted to record the incidence of P.R. 1059 malady. The results showed that the extcnt of chlorotic bandings varied with localities. At Colonia Camyanilla Ton Baja, Colonia Ingmio, Caño Tiburones, Contul Tgualdad, and ('entral Cayty (table 1), where the average 
maxinum femperature in the summer of $196+$ was generally under $86^{\circ} \mathrm{F}$,

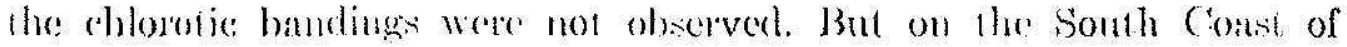

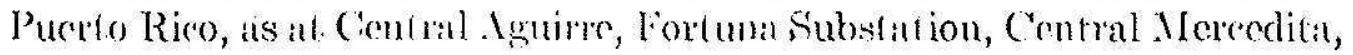
Tajas Valley, and Lajats substation, when: lles average maximum tomperature in the stmmere of lo(it wats aromel s) $1 \%$, banded rhlorosis was foumd widesperad.

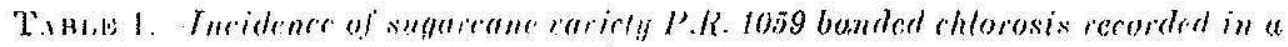

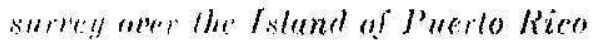

\begin{tabular}{|c|c|c|c|c|c|}
\hline \multirow{2}{*}{ localities } & \multirow{2}{*}{ fise of cinte } & \multirow{2}{*}{$\begin{array}{l}\text { Fitent of banded } \\
\text { chlorisis obserwed }\end{array}$} & \multicolumn{3}{|c|}{$\begin{array}{c}\text { Ingt average natsimam } \\
\text { temperatere }\end{array}$} \\
\hline & & & M:1y & June & July \\
\hline ...... & Whiths & $1+\ldots$ & $\%$ & 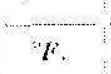 & $\%$ \\
\hline Colomia C'mmpanilla, 'loa Raja & 3 & Nut obsarved & & $\cdots$ & $\cdots \cdots$ \\
\hline Colonia Ingenio, Jon I3njat & 10) & do. & $\ldots \ldots$ & - & - \\
\hline Cunn Tiburmas & $i-1 j$ & dos. & & - & - \\
\hline Isulecla & $s$ & A lew cases & 86.5 & 85.10 & 85.10 \\
\hline D) & i; & do. & $8 t ; .5$ & $85,+10$ & 85.10 \\
\hline lgualdarl & i & Jot abservad & $\cdots-$ & $\rightarrow$ & $-\cdots$ \\
\hline Do. & 1 & do. & & $\ldots \ldots$. & $\ldots$ \\
\hline Contral ciney & j̆ & ilu. & 85.1 & $\cdots$ & $8: 3.80$ \\
\hline Centril Agnime & 50 & Very widespread & 90.3 & -..- & 91.50 \\
\hline Fortutar fubstation & $\tilde{j}$ & do. & 90.2 & 90.9 & $! 0.30$ \\
\hline Contral Mercedita & $\bar{\imath}$ & Widespread & 89.8 & 00.40 & 90.20 \\
\hline ('sutiral Rutima & 2 & Sot olsererved & $\ldots \ldots$ & $\ldots$ & \\
\hline Laijas Valley & (i & Fery widesprend & 90.2 & 91.40 & 91.00 \\
\hline Lajals Sulstalion & 5 & Widespread & 90.2 & 01.40 & 01.00 \\
\hline Ríu l’édras (solís) & $9-10$ & A few rasers & 88.8 & 87.90 & $6(i .80$ \\
\hline (imalsu & 78 & dn. & 80.8 & 89.60 & $.5 \times .30$ \\
\hline$\ldots \ldots$ & $\cdots \cdots$ & ......... & $\cdots-$ & $\cdots$ & \\
\hline
\end{tabular}

\section{DISCA SSIO)}

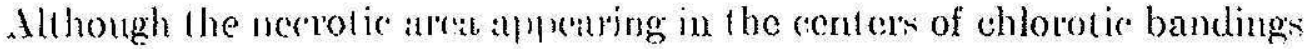
wembles the symptoms of rhlorotic striek to some extent, the regular palfern of ehlototic bandings atrow both sides of the michib has not been known to be produced by chlorotic streak. Alcoording to liaris (2), the nocrotic areas and leat'-ipliting were caused by the socondary fungus parasile, Comiolhyrium sp. In our atse, the secondary fungus parasite would probathly be /folminthosporium s\}). or (Collelotrichum sp).

The sympt oms of (hlorot ie banding on P.R. 10;9 are similar to the symploms deregibed by faris (2), and Martin (3) for the banded chlornis of sugarram. Based on the lyje of symploms observed, logether with the late that to causal agent hats so far been isolated, the chlorotic banding 
has been tentalively identified ax "banded rblorosis" "auned by high air remperatures, or a toxic substanee as loumd by Felgerton (l).

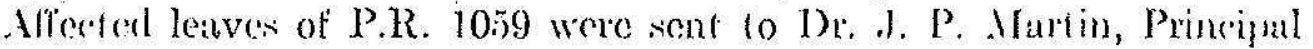
I'athologist, lexperiment Slation of Hawaiian Sugar Pantel's Asoctiation, Honolulu, Hawaii, for his opinion.

In his rejly, Doctor Mtatin wote:

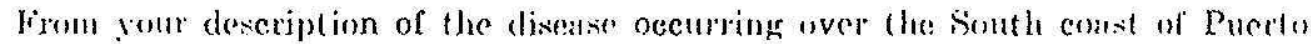
Rien on leaves of P.R. 1050, it is very likely that the tronble is a turn of handed chlorosis. This condition may be bronght about, usually, by low tomperatures but,

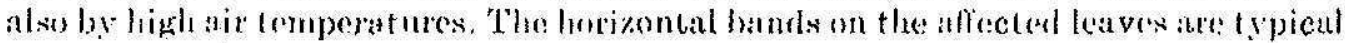
syuptoms of banded chlorosis and the pesition of the bands on the lataves indientes

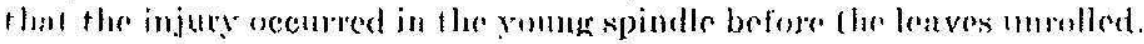

Ireording to Varlin (3), the cronomic losises from bambed chlorosis are ustally small. At change of varety may be indiealed if the chlorosis develops too frecuently, but specific control measures generally are not newesiry. Fintunately, as the cool season advanew, the symptom of chlorotic bandings disapperits from the leaves of P.R. 10;9.

\section{SIMMAR)}

Chlorotic banding was tirst observed in Puerto Riro on the leaves of sugarcane P.R. 10:39 at Central Agume. Since P.R. 10.79 is at promising sugarcune variety, the trouble has caused rousiderable concern. A survey showed that the extent of ehlorotic handing; varied with localities. A study of the records of the temperalure paliterns during the smmmer of 1964 showed that an outbreak of banding oc'urred mostly where high air $1 \mathrm{em}$ peratures had prevailed. As the rool seison advanced, the symyntom of chlorotir banding disilypeared from the leaves of P.R. 1059. Since the symptoms are similar (o those describol for banded chlorosis of sugarcane, but no causal agent has been identitied, the malady has becn iontallively identitied as bunded chlorosis cansed by high itr temperatures.

\section{BESUMEN}

Lí cnfermedad conocida como franja chorótica se observó por primera vez en P'uerto Rico en la Contral Aguirre en hojas de riña le la viricdad P.1R. 1059. Por ser éta una variedad prometedora, la presencia de la cufermedad lue motivo de gran preocupación. Cn sistudio realizado reveló rue la soveridad de la enfermedad variaba según donde se senubrara la caña. Los records de temperalura que se registruon durance el verano de 1964 demuestran que los brotes de esta cnfermedad tenían lugar mayormente cuando la tcmporal ura ambiental cra alta. Al aproximarso lia fomporada fiesca, lossíntomas de la franja clorótica desparcen de las hojas de la variedad P.R. 1059. Por la similaridad de estos síntomas a los que se 
clescriben en el caso de la franj: clorólica de la caña de azúcar, y por no haberse atislado el agente patogéniro, la cufrrmedad se hit identificudo coulativimente como franja clorótica causada por lis altas tempernturus.

\section{LITEIRA'TURE CITISD}

1. Ligerton, C. IV., Sugareane and Its Diseases, 2nd ed., Louistana Statr l'uiv. Press, Batom Romge, La., pp, 301, 1958.

2. karis, J. A., Cold chlurosis of sugareane, Phytoputhology 16:885-91, 1926),

3. Martin, J. P., Wismer, C. A., and Hughes, C. G., Lovirnnmental diffects, Sugat-

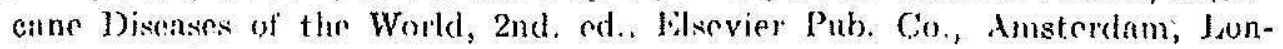
don, $p$ p. 240-61, 1964.

1. Necombe, F., and lee, $\mathrm{H}$. A., The canse uf sectional chlorusis ut sugureane, $H a-$ writian Mlanter's Rer. 31: 125 8. 1927.

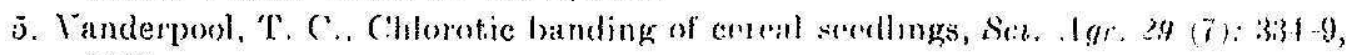
1949.

\section{ERRATUNI}

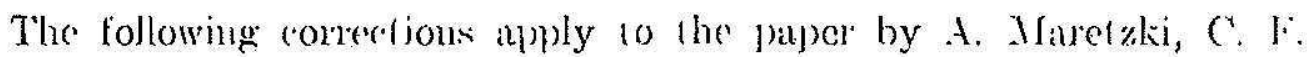
Asenjo, H. A. Tens, J.A.L'.P. 50(1): 1-9) (1966).

p. .) lines 10-13

"... The level of ascorbic acid in acerola leaves fluctuated betwcen ("a. 22 micromoles/gm. at periods of active fruit development, and 10 micromoles igm. cluring relatively dotmant periods." 